\title{
Comparative Efficacy of Botanical Pesticides against Sucking Insect Pests of Mustard Crop
}

\section{Arshad Ali Essani ${ }^{1}$, Bhai Khan Solangi ${ }^{1}$, Muhammad Ilyas Abro ${ }^{2}$, Sultan Ahmed ${ }^{3}$, Karim Bakhsh Sial ${ }^{3}$, Muhammad Saleem ${ }^{4}$, Ali Asghar Gola ${ }^{5}$, Ghulam Ali ${ }^{6}$, Moula Dad ${ }^{6}$, Mujeeb ur Rehman ${ }^{6}$, Habibullah Kakar $^{6}$ and Mitha Khan ${ }^{6 *}$}

${ }^{1}$ Department of Entomology, Sindh Agriculture University, Tandojam, Pakistan; ${ }^{2}$ College Education Department Govt. of Sindh, Pakistan; ${ }^{3}$ Cotton Resaerch Station Lasbela and Sibi Balochistan, Pakistan; ${ }^{4}$ Director Agriculture Research Water Management and HEIS ARI Quetta, Pakistan; ${ }^{5}$ Agriculture Officer Market Committee DM Jamali Naseerabad, Pakistan; ${ }^{6}$ Agriculture Research Institute ARI Balochistan, Pakistan.

Abstract | The experiment was conducted at experimental field of Entomology Section, Agriculture Research Institute, Tandojam during the season 2018-19. Maximum reduction in thrips population (30.3\%) was observed in plot sprayed with neem seed extract followed by plot sprayed with neem oil (24.47\%), tobacco extract $(22.00 \%)$ and akk plant extract (19.83). Neem seed extract showed higher efficacy (81.01\%) against thrips population on mustard crop followed by neem oil (66.13\%), tobacco extract $(58.20 \%)$ and akk plant extract (53.12\%). Maximum reduction in whitefly population $(13.00 \%)$ was observed in plot sprayed with neem seed extract followed by plot sprayed with neem oil $(10.33 \%)$, tobacco extract $(9.50 \%)$ and akk plant extract (7.33\%). Neem seed extract showed higher efficacy $(88.67 \%)$ against whitefly population on mustard crop followed by neem oil (80.51\%), tobacco extract (79.16\%) and akk plant extract (64.69\%). Maximum reduction in aphid population $(14.33 \%)$ was observed in plot sprayed with neem seed extract followed by plot sprayed with neem oil (11.10\%), tobacco extract (10.23\%) and akk plant extract (9.60\%). Neem seed extract showed higher efficacy (87.75\%) against aphid population on mustard crop followed by neem oil (76.02\%), tobacco extract $(71.38 \%)$ and akk plant extract (68.57\%). Maximum reduction in painted bug population (8.67\%) was observed in plot sprayed with neem seed extract followed by plot sprayed with neem oil (8.00\%), tobacco extract (7.66\%) and akk plant extract (6.76\%). Neem seed extract showed higher efficacy (83.93\%) against painted bug population on mustard crop followed by neem oil (77.44\%), tobacco extract (71.85\%) and akk plant extract (67.60\%). Maximum crop yield (22 kg/plot) were recorded when the neem seed extract was sprayed on mustard crop; followed by average crop yield of 20 and 18/plot when the mustard crop were sprayed with neem oil and tobacco extract, respectively. However, the lower crop yield (18 kg/plot) was noticed when the mustard crop were sprayed with akk plant extract. The control plots resulted in lowest crop yields of $10 \mathrm{~kg} /$ plot. It was concluded that neem seed extract ranked $1^{\text {st }}$ in reduction of the thrips, whitefly, aphid and painted bug population followed by neem oil ranked $2^{\text {nd }}$, tobacco extract ranked $3^{\text {rd }}$ and akk plant extract ranked $4^{\text {th }}$ in reduction of pests population. Maximum efficacy against thrips, whitefly, aphid and painted bug population was counted in plot sprayed with neem seed extract followed by neem oil, tobacco extract and akk plant extract. Moreover, the pests population remained constant in un-treated (control) plot throughout the experiment.

Received | August 07, 2020; Accepted | October 08, 2020; Published | October 17, 2020

*Correspondence | Mitha Khan, Agriculture Research Institute ARI Balochistan, Pakistan; Email: mithakhan86.mk@gmail.com

Citation | Essani, A.A., B.K. Solangi, M.I. Abro, S. Ahmed, K.B. Sial, M. Saleem, A.A. Gola, G. Ali, M. Dad, M. Rehman, H. Kakar and M. Khan. 2020. Comparative efficacy of botanical pesticides against sucking insect pests of mustard crop. Pakistan Journal of Agricultural Research, 33(4): 820-826.

DOI | http://dx.doi.org/10.17582/journal.pjar/2020/33.4.820.826

Keywords | Efficacy, Botanical pesticide, Insect pests, Mustard crop

December 2020 | Volume 33 | Issue 4 | Page 820 
Introduction

$\mathrm{R}$ apeseed (Brassica spp.) is grown primarily for its seed which yields about $40 \%$ oil and a highprotein animal feed. The scientists have sequenced the entire genome of rapeseed/canola (Brassica napus) and its constituent genomes present in Brassica rapa and Brassica oleracea in 2009 (Fekri et al., 2013). Brassica napus (canola) is covered with more bloom than other species. It is very late in maturity and remains green untill about the middle of April. Canola oil is the lowest in saturated fat, containing only $6 \%$ saturated fat and is high in mono-saturated fat. This has $50 \%$ less saturated fat than corn oil (Pradhan, 2012). Rapeseed oil generally contains a high level of erucic acid, which is mildly toxic to humans in large doses. Traditional and other uses have been for lamp oils, soap making, high-temperature and tenacious high-erucic acid lubricating oils, and plastics manufacturing. With the shift to rapeseed in the European Union, the low erucic acid content of rapeseed oil and its specific fatty acid composition make it highly appreciated edible oil. Apart from the agronomic factors, the decrease in production was also contributed by insect pest infestation. Among insect pests infesting oilseeds, sucking complex cause is a major factor constrains increased yields (Toscano e al., 2012).

According to 38 insect pests are known to be associated with rapeseed mustard crop in India. On the basis of their economic importance, the insect pests of mustard crop may be group into, key pest:aphid, Lipaphis erysimi (Kaltenbach), major pests: sawfly, Athalia lugens proxima (Klug); painte bug, Bagrada cruciferarum Kirkaldy and leafminer, Chromatomyia borticola Goureau, minor pests: Bihar hairy caterpillar, Diacrisia abliqua Walker; cabbage butterfly, Pieris brassicae Linnaeus; flea beetle, Pbyllotreta cruciferae Goeze and green phid, Myzus persicae Seltzer, new pests:leafwebber, Crocidolomia binotalis Zeller; borer, Hellula undalis Fabricius and whitefly, Bemisia tabaci Gennadius. Among these, aphid, L. erysimi is the key pest in all the mustard growing regions of the country. The nymphs and adults of the aphid suck the cell sap from the minflorescence, terminal twig, siliqua (pod), leaves and branches. On evere infestation, plant gets poor pod formation, leaves get curled, shrivel and plants become completely dried. Rohilla et al. (2015) reported that $L$. erysimi is most destructive insect causing severe reduction in seed yield varying from 15.0 to $73.3 \%$; while Verma (2013) found mustard aphid Lipaphis erysimi (Kalt.), Thrip Thrip tabaci and Whitefly Bemesia tabaci (Gennedius) as the major insect pests of mustard. Panda and Khush (2013) found that varieties with thicker pods suppressed insect pest infestation and showed resistance in diseases transmitted by insects; while Karmakar (2013) compared mustard cultivars B-9, NC-1, RW351 and PGS-1004 for resistance to Lipaphis erysimi and found that lowest aphid population was recorded on PGS-1004 and this cultivar also showed higher yield than rest of the cultivars. Singh (2006) reported that Indian mustard showed relative resistance to Lipaphis erysimi; while Saljoqi (2006) reported that most of the hybrid mustard cultivars with thicker stems were resistant to Lipaphis erysimi and mustard sawfly. Sahito et al. (2010) indicated that the white fly Bemisia tabaci,(Genn).Mustard aphid Lipaphis erysimi (Kalt) and Bagrada picta (F) were major mustard insect pests and showed that higher $(6.71+0.98 /$ leaf) whitefly Bemisia tabaci population buildup was recorded on Indian mustard variety 'Yellow sarsoon' as compared to mustard variety 'Dark green leaves' (6.30 + 0.61), Indian mustard variety 'Brown sarsoon' (6.19 + 0.63), local mustard variety 'Raya Anmol' (5.40 + $0.55)$, local mustard variety 'Torya Early' $(5.38+0.57)$ and Indian mustard variety 'Rai S-9' $(3.79+0.50)$. Das et al. (2013) showed that relative humidity and rainfall had negative influence on pests and natural enemies during the study period. On the other hand, aphid produces a good amount of honey dew which facilitates the growth of the fungus that makes the leaves appeardirty black.

Among various biotic factors responsible for reducing the yield of rapeseed mustard, insect pests are the major one. Thirty eight insect pests are known to be associated with rapeseed mustard crop in India Bakhetia and Sekhon (1989). Lipaphis erysimi causes 35.4 to $96 \%$ yield loss, 30.9 percent seed weight loss and 2.75 pecentoil loss (Bakhetia and Sekhon, 1989). In view of combating the notorious pest, the present investigation was under take to study the incidence and management of mustard aphid.

\section{Materials and Methods}

The experiment was conducted at Entomology section (A.R.I), Tando jam. The variety of Sindh Raya was sown with plot size $110 \times 85\left(9350 \mathrm{ft}^{2}\right)$. The four botanical pesticides were tested to evaluate the performance against insect pests of mustard 
crop in randomize complete block design with three replications.

\section{Preparation of botanical extracts}

Treatments $=5$

$\mathrm{T}_{1}=\operatorname{Neem}$ powder $(3-4 \mathrm{~kg}) \mathrm{T}_{2}=\operatorname{Akk}(2-3 \mathrm{~kg}) \mathrm{T}_{3}=$ Tobbaco $(2-3 \mathrm{~kg}) \mathrm{T}_{4}=$ Neem oil $(900-1100 \mathrm{~g}) \mathrm{T}_{5}=$ Control (untreated)

The plant material was boiled in 10 litter of water per acre. A volume of (1354 gram neem seed after 1700 $\mathrm{ml}$ with add 5 liter water, 1500 gram Tobacco after $1600 \mathrm{ml}$ with add 5 liter water, neem oil $250 \mathrm{ml}$ and 1760 gram Akk leaves after $3600 \mathrm{ml}$ with add 5 liter water), After boiling filtered through muslin cloth. after preparing stock solution the musturd crop was sprayed with a knapsack hand sprayer. The solution was added with required water calibrate earlier for spray the mustard crop. The prepare dose neem seed was $206 \mathrm{ml}$ and neem oil $37 \mathrm{ml}$ and Tobbaco was 131 $\mathrm{ml}$ and Akk was $261 \mathrm{ml}$ for spray the musturd crop.

The observation was taken from 5 plant randomly selected and from each plant 5 leaves was observed. Two leaves from bottom, two leaves from middle and one leave from top portion of mustard plant. The pre treatment observation was taken before treatment and post treatment observation after spray 24 hours, 48 hours, 72 hours, 96 hours and one week. The significance of the botanical pesticide was evaluated using analysis at least significant difference.

\section{Results and Discusion}

Efficacy of various botanical pesticides against thrips (Thrips tabaci) population on mustard crop after spray The results in regards to efficacy of various botanical pesticides against thrips population on mustard crop after spray is presented in Table 1 . The data showed that before spray of various botanical pesticides the thrips population was recorded as $37.40,37.33,37.80$ and 37.00 nymph/plant in various plots, respectively. After spray of 24 hours the thrips population was recorded as 31.15, 35.40, 31.33 and 31.00 nymph/ plant in plots sprayed with neem seed extract, akk plant extract, tobacco extract and neem oil, respectively. The thrips population linearly declined after spray of 48 , 72 and 96 hours of spray and reached at lowest level after 1 week of spray with average population of 7.10 , 17.50, 15.00 and 13.33 nymph/plant in plots sprayed with neem seed extract, akk plant extract, tobacco extract and neem oil, respectively. In control plot the thrips population remains constant before and after 24 h, 48 h, 72 h, 96 h and 1 week. Maximum pest reduction $(30.3 \%)$ was observed in plot sprayed with neem seed extract followed by plot sprayed with neem oil $(24.47 \%)$, tobacco extract $(22.00 \%)$ and akk plant extract (19.83). Neem seed extract showed higher efficacy (81.01\%) against thrips population on mustard crop followed by neem oil (66.13\%), tobacco extract (58.20\%) and akk plant extract (53.12\%). Statistical analysis of the obtained data revealed that there was significant $(\mathrm{p}<0.05)$ difference in thrips population on mustard crop between the botanical pesticides at various intervals.

\section{Efficacy of various botanical pesticides against whitefly (Bemisia tabaci) population on mustard crop after spray} The results in regards to efficacy of various botanical pesticides against whitefly population on mustard crop after spray is presented in Table 2. The data showed that before spray of various botanical pesticides the whitefly population was recorded as $14.66,11.33,12.00$ and 12.83 nymph /plant in various plots, respectively. After spray of 24 hours the whitefly population was recorded as $8.00,10.00,9.50$ and 8.33 nymph/plant in plots sprayed with neem seed extract, akk plant extract, tobacco extract and neem oil, respectively. The whitefly population linearly declined after spray of 48 , 72 and 96 hours of spray and reached at lowest level after 1 week of spray with average population of 1.66 , 4.00, 3.12 and 2.50 nymph/plant in plots sprayed with neem seed extract, akk plant extract, tobacco extract and neem oil, respectively. In control plot the whitefly population remains constant before and after $24 \mathrm{~h}, 48 \mathrm{~h}, 72 \mathrm{~h}, 96 \mathrm{~h}$ and 1 week. Maximum pest reduction $(13.00 \%)$ was observed in plot sprayed with neem seed extract followed by plot sprayed with neem oil (10.33\%), tobacco extract (9.50\%) and akk plant extract $(7.33 \%)$. Neem seed extract showed higher efficacy $(88.67 \%)$ against whitefly population on mustard crop followed by neem oil (80.51\%), tobacco extract (79.16\%) and akk plant extract (64.69\%). Statistical analysis of the obtained data revealed that there was significant $(\mathrm{p}<0.05)$ difference in whitefly population on mustard crop between the botanical pesticides at various intervals.

Efficacy of various botanical pesticides against aphid (Lipaphis eryisimi) population on mustard crop after spray The results in regards to efficacy of various botanical pesticides against aphid population on mustard crop 
after spray is presented in Table 3. The data showed that before spray of various botanical pesticides the aphid population was recorded as $16.33,14.33,14.00$, 14.60 nymph/plant in various plots, respectively. After spray of 24 hours the aphid population was recorded as $11.33,12.50,12.00$ and 11.33 nymph/plant in plots sprayed with neem seed extract, akk plant extract, tobacco extract and neem oil, respectively. The aphid population linearly declined after spray of 48,72 and 96 hours of spray and reached at lowest level after 1 week of spray with average population of $2.00,4.40$, 4.10 and 3.50 nymph/plant in plots sprayed with neem seed extract, akk plant extract, tobacco extract and neem oil, respectively. In control plot the aphid population remains constant before and after $24 \mathrm{~h}, 48$ h, $72 \mathrm{~h}, 96 \mathrm{~h}$ and 1 week. Maximum pest reduction (14.33\%) was observed in plot sprayed with neem seed extract followed by plot sprayed with neem oil (11.10\%), tobacco extract (10.23\%) and akk plant extract (9.60\%). Neem seed extract showed higher efficacy $(87.75 \%)$ against aphid population on mustard crop followed by neem oil (76.02\%), tobacco extract (71.38\%) and akk plant extract (68.57\%). Statistical analysis of the obtained data revealed that there was significant $(p<0.05)$ difference in aphid population on mustard crop between the botanical pesticides at various intervals.

Efficacy of various botanical pesticides against painted bug (Bagrada cruciferarum) population on mustard crop after spray

The results in regards to efficacy of various botanical pesticides against painted bug population on mustard crop after spray is presented in Table 4. The data showed that before spray of various botanical pesticides the painted bug population was recorded as $10.33,10.00,10.66,10.33$ nymph/plant in various plots, respectively. After spray of 24 hours the painted bug population was recorded as $6.66,8.00,7.80$ and 7.60 nymph/plant in plots sprayed with neem seed extract, akk plant extract, tobacco extract and neem oil, respectively. The painted bug population linearly declined after spray of 48, 72 and 96 hours of spray and reached at lowest level after 1 week of spray with average population of 1.66, 3.24, 3.00 and 2.33 nymph/plant in plots sprayed with neem seed extract, akk plant extract, tobacco extract and neem oil, respectively. In control plot the painted bug population remains constant before and after $24 \mathrm{~h}, 48$ h, $72 \mathrm{~h}, 96 \mathrm{~h}$ and 1 week. Maximum pest reduction (8.67\%) was observed in plot sprayed with neem seed extract followed by plot sprayed with neem oil (8.00\%), tobacco extract (7.66\%) and akk plant extract (6.76\%). Neem seed extract showed higher efficacy (83.93\%) against painted bug population on mustard crop followed by neem oil (77.44\%), tobacco extract (71.85\%) and akk plant extract (67.60\%). Statistical analysis of the obtained data revealed that there was significant $(p<0.05)$ difference in painted bug population on mustard crop between the botanical pesticides at various intervals.

\section{Mustard yield (kg/plot)}

The data regarding crop yield plot $^{-1}$ (Table 5 ) indicates that maximum crop yield $(22 \pm 2.40 \mathrm{~kg} / \mathrm{plot})$ were recorded when the neem seed extract was sprayed on mustard crop; followed by average crop yield of $20 \pm 2.00$ and $18 \pm 1.84 \mathrm{~kg} / \mathrm{plot}$ when the mustard crop were sprayed with neem oil and tobacco extract, respectively. However, the lower crop yield $(16 \pm 1.20$ $\mathrm{kg} / \mathrm{plot}$ ) was noticed when the mustard crop were sprayed with akk plant extract. The control plots resulted in lowest crop yields of $10 \pm 1.10 \mathrm{~kg} /$ plot. This indicates that the neem seed and neem oil showed a remarkable performance resulting in a minor difference in crop yield, because botanical extracts also kept the insect pests below the economic injury level. Moreover, neem seed extract and neem oil is the cheap sources and cost effective to combat the mustard insect pests.

The findings of the present study showed that neem seed extract ranked $1^{\text {st }}$ in reduction of the thrips, whitefly, aphid and painted bug population followed by neem oil ranked $2^{\text {nd }}$, tobacco extract ranked $3^{\text {rd }}$ and akk plant extract ranked $4^{\text {th }}$ in reduction of pests population. Maximum efficacy against thrips, whitefly, aphid and painted bug population was counted in plot sprayed with neem seed extract followed by neem oil, tobacco extract and akk plant extract. Whereas, the pests population remained constant in un-treated (control) plot throughout the experiment. The results of the present study are further confirmed by those of Kumar (2003) reported that neem extract gave maximum mortality against jassid and fruit borer compared with Achook and NSKE (3\%). Haq (2006) also reported similar findings and stated that botanical pesticide (neem products) were highly effective for eradication and controlling sucking insect pests particularly whitefly, jassid, aphid and fruit borer under field conditions. On the otherhand, Hassan (2006) jassid population significantly control through 
Table 1: Efficacy of various botanical pesticides against thrips (Thrips tabaci) population on mustard crop.

\begin{tabular}{|c|c|c|c|c|c|c|c|c|}
\hline $\begin{array}{l}\text { Botanical } \\
\text { extracts }\end{array}$ & Pre obs. & $24 \mathrm{~h}$ & $48 \mathrm{~h}$ & $72 \mathrm{~h}$ & $96 \mathrm{~h}$ & 1 week & $\begin{array}{l}\text { Pest reduc- } \\
\text { tion / plant }\end{array}$ & $\begin{array}{l}\text { Efficacy } \\
\text { (\%) }\end{array}$ \\
\hline $\mathrm{T}_{1}=$ Neem seed & $37.40 \pm 15.20 \mathrm{a}$ & $31.15 \pm 12.50 \mathrm{c}$ & $25.30 \pm 10.30 \mathrm{~d}$ & $20.10 \pm 8.30 \mathrm{~d}$ & $15.33 \pm 7.20 \mathrm{~d}$ & $7.10 \pm 2.10 \mathrm{e}$ & 30.3 & 81.01 \\
\hline $\mathrm{T}_{2}=\mathrm{Akk}$ plant & $37.33 \pm 15.10 \mathrm{a}$ & $35.40 \pm 14.40 \mathrm{~b}$ & $33.30 \pm 12.60 \mathrm{~b}$ & $29.20 \pm 10.30 \mathrm{~b}$ & $25.33 \pm 11.30 \mathrm{~b}$ & $17.50 \pm 5.80 \mathrm{~b}$ & 19.83 & 53.12 \\
\hline $\mathrm{T}_{3}=$ Tobbaco & $37.80 \pm 15.40 \mathrm{a}$ & $31.33 \pm 10.60 \mathrm{c}$ & $29.33 \pm 11.20 \mathrm{c}$ & $27.33 \pm 8.60 \mathrm{c}$ & $22.13 \pm 8.90 c$ & $15.00 \pm 4.20 \mathrm{c}$ & 22.00 & 58.20 \\
\hline $\mathrm{T}_{4}=$ Neem oil & $37.00 \pm 15.05 a$ & $31.00 \pm 10.20 c$ & $29.00 \pm 11.03 c$ & $27.00 \pm 8.20 c$ & $20.00 \pm 7.60 \mathrm{~d}$ & $13.33 \pm 3.50 \mathrm{~d}$ & 24.47 & 66.13 \\
\hline T5=Control & $40.00 \pm 20.30 \mathrm{a}$ & $38.00 \pm 16.50 \mathrm{a}$ & $42.00 \pm 22.30 \mathrm{a}$ & $40.00 \pm 20.50 \mathrm{a}$ & $43.00 \pm 23.50 \mathrm{a}$ & $40.66 \pm 20.80 \mathrm{a}$ & -0.66 & 1.65 \\
\hline S.E. \pm & 1.8257 & 1.5251 & 17.5010 & 20.9322 & 28.9322 & 33.8738 & - & - \\
\hline LSD 0.05 & 4.2102 & 4.3310 & 20.3102 & 24.4556 & 30.4556 & 36.3210 & - & - \\
\hline
\end{tabular}

Table 2: Efficacy of various botanical pesticides against whitefly (Bemisia tabaci) population on mustard crop.

$\begin{array}{lllllllll}\begin{array}{l}\text { Botanical } \\ \text { extracts }\end{array} & \text { Pre obs. } & \mathbf{2 4 h} & \mathbf{4 8 h} & \mathbf{7 2 h} & \mathbf{9 6 h} & \mathbf{1 ~ w e e k} & \begin{array}{l}\text { Pest reduc- } \\ \text { tion/plant }\end{array} & \begin{array}{l}\text { Efficacy } \\ \text { (\%) }\end{array} \\ \mathrm{T}_{1}=\text { Neem seed } & 14.66 \pm 5.30 & 8.00 \pm 3.40 \mathrm{e} & 5.20 \pm 2.80 \mathrm{e} & 3.33 \pm 2.20 \mathrm{e} & 2.10 \pm 1.30 \mathrm{e} & 1.66 \pm 0.84 \mathrm{e} & 13.00 & 88.67 \\ \mathrm{~T}_{2}=\text { Akk plant } & 11.33 \pm 4.20 & 10.00 \pm 3.90 \mathrm{~b} & 8.00 \pm 3.20 \mathrm{~b} & 6.20 \pm 2.40 \mathrm{~b} & 5.24 \pm 2.10 \mathrm{~b} & 4.00 \pm 1.60 \mathrm{~b} & 7.33 & 64.69 \\ \mathrm{~T}_{3}=\text { Tobbaco } & 12.00 \pm 4.80 & 9.50 \pm 4.10 \mathrm{c} & 7.33 \pm 3.80 \mathrm{c} & 5.50 \pm 3.20 \mathrm{c} & 4.10 \pm 2.10 \mathrm{c} & 3.12 \pm 1.60 \mathrm{c} & 9.50 & 79.16 \\ \mathrm{~T}_{4}=\text { Neem oil } & 12.83 \pm 5.10 & 8.33 \pm 3.50 \mathrm{~d} & 6.66 \pm 2.80 \mathrm{~d} & 5.00 \pm 2.10 \mathrm{~d} & 4.00 \pm 1.80 \mathrm{~d} & 2.50 \pm 1.10 \mathrm{~d} & 10.33 & 80.51 \\ \text { T5=Control } & 15.40 \pm 6.30 & 12.40 \pm 5.20 \mathrm{a} & 13.50 \pm 5.80 \mathrm{a} & 13.00 \pm 5.30 \mathrm{a} & 14.20 \pm 6.10 \mathrm{a} & 15.30 \pm 6.40 \mathrm{a} & 0.10 & 0.64 \\ \text { S.E. } \pm & 1.3499 & 1.2996 & 1.2996 & 1.2649 & 1.2996 & 1.4644 & -- & -- \\ \text { LSD 0.05 } & 3.1129 & 2.9968 & 2.9968 & 2.9169 & 2.9968 & 3.3769 & -- & --\end{array}$

Table 3: Efficacy of various botanical pesticides against aphid (Lipaphis eryisimi) population on mustard crop.

$\begin{array}{lllllllll}\begin{array}{l}\text { Botanical ex- } \\ \text { tracts }\end{array} & \text { Pre obs. } & \mathbf{2 4 h} & \mathbf{4 8} \mathbf{h} & \mathbf{7 2 h} & \mathbf{9 6 h} & \mathbf{1} \text { week } & \begin{array}{l}\text { Pest reduc- } \\ \text { tion } / \text { plant }\end{array} & \begin{array}{l}\text { Efficacy } \\ \text { (\%) }\end{array} \\ \mathrm{T}_{1}=\text { Neem seed } & 16.33 \pm 8.60 & 11.33 \pm 5.30 \mathrm{c} & 9.33 \pm 4.10 \mathrm{c} & 7.33 \pm 3.50 \mathrm{c} & 5.33 \pm 2.80 \mathrm{c} & 2.00 \pm 1.10 \mathrm{~d} & 14.33 & 87.75 \\ \mathrm{~T}_{2}=\text { Akk plant } & 14.00 \pm 7.20 & 12.50 \pm 5.80 \mathrm{~b} & 10.40 \pm 5.10 \mathrm{~b} & 8.50 \pm 4.90 \mathrm{~b} & 6.33 \pm 3.20 \mathrm{~b} & 4.40 \pm 2.33 \mathrm{~b} & 9.60 & 68.57 \\ \mathrm{~T}_{3}=\text { Tobbaco } & 14.33 \pm 7.90 & 12.00 \pm 6.80 \mathrm{~b} & 10.00 \pm 5.20 \mathrm{~b} & 8.00 \pm 4.10 \mathrm{~b} & 5.10 \pm 3.20 \mathrm{c} & 4.10 \pm 2.50 \mathrm{~b} & 10.23 & 71.38 \\ \mathrm{~T}_{4}=\text { Neem oil } & 14.60 \pm 8.10 & 11.33 \pm 7.60 \mathrm{c} & 9.50 \pm 7.20 \mathrm{c} & 7.40 \pm 5.30 \mathrm{c} & 5.33 \pm 2.50 \mathrm{c} & 3.50 \pm 2.10 \mathrm{c} & 11.10 & 76.02 \\ \mathrm{~T} 5=\text { Control } & 15.33 \pm 8.80 & 14.33 \pm 8.10 \mathrm{a} & 12.33 \pm 7.60 \mathrm{a} & 14.33 \pm 8.01 \mathrm{a} & 15.33 \pm 8.50 \mathrm{a} & 15.00 \pm 8.30 \mathrm{a} & 0.33 & 2.15 \\ \text { S.E. } \pm & 1.5951 & 1.5951 & 1.6433 & 1.5094 & 1.5811 & 1.4644 & -- & \\ \text { LSD 0.05 } & 3.6784 & 3.6784 & 4.5244 & 3.6074 & 3.6461 & 3.3769 & -- & \end{array}$

Table 4: Efficacy of various botanical pesticides against painted bug (Bagrada cruciferarum) population on mustard crop.

\begin{tabular}{|c|c|c|c|c|c|c|c|c|}
\hline $\begin{array}{l}\text { Botanical ex- } \\
\text { tracts }\end{array}$ & Pre obs. & $24 \mathrm{~h}$ & $48 \mathrm{~h}$ & $72 \mathrm{~h}$ & $96 \mathrm{~h}$ & 1 week & $\begin{array}{l}\text { Pest reduction } \\
\text { / plant }\end{array}$ & $\begin{array}{l}\text { Efficacy } \\
(\%)\end{array}$ \\
\hline $\mathrm{T}_{1}=$ Neem seed & $10.33 \pm 5.10$ & $6.66 \pm 4.16 \mathrm{e}$ & $5.00 \pm 3.80 \mathrm{e}$ & $3.00 \pm 3.10 \mathrm{e}$ & $1.33 \pm 0.91 \mathrm{e}$ & $1.66 \pm 0.50 \mathrm{e}$ & 8.67 & 83.93 \\
\hline $\mathrm{T}_{2}=\mathrm{Akk}$ plant & $10.00 \pm 4.80$ & $8.00 \pm 3.50 \mathrm{~b}$ & $7.33 \pm 2.90 \mathrm{~b}$ & $6.80 \pm 2.40 \mathrm{~b}$ & $5.66 \pm 2.10 \mathrm{~b}$ & $3.24 \pm 1.95 b$ & 6.76 & 67.60 \\
\hline $\mathrm{T}_{3}=$ Tobbaco & $10.66 \pm 5.13$ & $7.80 \pm 4.40 \mathrm{c}$ & $6.66 \pm 4.10 \mathrm{c}$ & $5.40 \pm 3.20 c$ & $4.20 \pm 2.80 c$ & $3.00 \pm 2.10 \mathrm{c}$ & 7.66 & 71.85 \\
\hline $\mathrm{T}_{4}=$ Neem oil & $10.33 \pm 5.05$ & $7.60 \pm 4.10 \mathrm{~d}$ & $6.10 \pm 3.50 \mathrm{~d}$ & $4.33 \pm 3.10 \mathrm{~d}$ & $3.66 \pm 2.50 \mathrm{~d}$ & $2.33 \pm 1.80 \mathrm{~d}$ & 8.00 & 77.44 \\
\hline T5=Control & $9.33 \pm 4.20$ & $9.66 \pm 4.80 \mathrm{a}$ & $9.00 \pm 4.40 \mathrm{a}$ & $9.33 \pm 4.20 \mathrm{a}$ & $9.66 \pm 4.80 \mathrm{a}$ & $8.66 \pm 5.40 \mathrm{a}$ & 0.67 & 7.18 \\
\hline S.E. \pm & 1.2293 & 1.2480 & 1.1205 & 1.1595 & 1.1824 & 1.4644 & -- & \\
\hline LSD 0.05 & 2.8347 & 2.8034 & 2.5839 & 2.6738 & 2.6098 & 3.3769 & -- & \\
\hline
\end{tabular}

the neem based products. Khattak (2006) stated that neem seed water extract $3 \%$ plus neem oil $2 \%$ spray against fruit borer and jassid significantly reduced the population. Dut (2007) reported that for controlling sucking insects pests of field crops botanical extracts such as dhatura and neem based products was 
preferable for effective IPM strategies. Noonari and Yadav (2008) they recored $71.97 \%$ mortality when the field sprayed with neem oil after $24,48,72 \mathrm{hrs}$ as well as one and two weeks, respectively. Noonari and Yadav (2008) reavled that formulation of azadirachtinendosulfan and neem gave $0.65 \%$ per plant reduction in jassid population.

\section{Table 5: Crop yield (kg/plot).}

$\begin{array}{ll}\text { Botanical extracts } & \text { Yield (kg/plot) } \\ \mathrm{T}_{1}=\text { Neem seed } & 22 \pm 2.40 \mathrm{a} \\ \mathrm{T}_{2}=\text { Akk plant } & 16 \pm 1.20 \mathrm{~d} \\ \mathrm{~T}_{3}=\text { Tobbaco } & 18 \pm 1.84 \mathrm{c} \\ \mathrm{T}_{4}=\text { Neem oil } & 20 \pm 2.00 \mathrm{~b} \\ \mathrm{~T} 5=\text { Control } & 10 \pm 1.10 \mathrm{e}\end{array}$

\section{Conclusions and Recommendations}

From the above findings it was concluded that neem seed extract ranked $1^{\text {st }}$ in reduction of the thrips, whitefly, aphid and painted bug population followed by neem oil ranked $2^{\text {nd }}$, tobacco extract ranked $3^{\text {rd }}$ and akk plant extract ranked $4^{\text {th }}$ in reduction of pests population. Maximum efficacy against thrips, whitefly, aphid and painted bug population was counted in plot sprayed with neem seed extract followed by neem oil, tobacco extract and akk plant extract. Whereas, the pests population remained constant in un-treated (control) plot throughout the experiment.

\section{Novelty Statement}

This is baseline study and information about the pesticides against sucking insect pests.

\section{Author's Contribution}

Arshad Ali Essani, Bhai Khan Solangi and Muhammad Ilyas Abro conceived the idea. Sultan Ahmed, Karim Bakhsh Sial and Muhammad Saleem wrote abstract. Ali Asghar Gola, Ghulam Ali and Moula Dad methodology, did SPSS analysis, conclusion. Mujeeb ur Rehman and Habibullah Kakar technical input at every step, overall management of the article, data collection, data entry in SPSS and analysis. Mitha Khan result and discussion, introduction, references.

\section{Conflict of interest}

The authors have declared no conflict of interest.

\section{References}

Bakhetia, D.R.C. and B.S. Sekhon. 1989. Insec pest and their management in rapeseed-mustard. J. Oil Seeds Res., 6: 269-273.

Das, 2013. Seasonal abundance of insect-pests on mustard varieties (Brassica spp.) and relation to abiotic factors. Ann. J. Biol., 31(1): 109-112.

Dut, 2007. Field efficacy of different insecticides against Helicoverpa armigera (Hubner) infesting chickpea. J. Legume Res., 33(4): 269273.

Fekri, 2013. Control of insect pests of toria, sarson and rai. Indian Farm., 36(4): 41-44.

Haq, 2006. insecticides against Helicoverpa armigera (Hubner) infesting chickpea. J. Legume Res., 33(4): 200-278.

Hassan, 2006. Relative efficacy of newer insecticides and biopesticides against Helicoverpa armigera (Hubner) in chickpea. J. Entomol. Zool. Stud., 15(3): 455-462.

Karmakar, 2013. Preliminary screening of national varieties of Brassica juncea (L.) (Czern and Coss) against mustard aphid, Lipaphis erysimi (Kalt.). J. Oilseeds Res., 7(2): 81-83.

Khatak, 2006. Bakhetia and Arora (1986. Chemical control of Helicoverpa armigera (Hubner) on chickpea. J. Maharashtra Agric. Univ., 23(1): 83-84.

Kumar, S., 2003. Insect pests of Canola crop (other than aphid). J. Agric. Biol. Sci., 1 (4): 19-21.

Noonari and Yadav, 2008. Relative efficacy of newer insecticides and biopesticides against Helicoverpa armigera (Hubner) in chickpea. J. Entomol. Zool. Stud., 15(3): 455-462.

Panda and Khush. 2013. Status of insect pests of cruciferous in U.P. India. J. Agric. Res., 12(1): 45-50.

Pradhan,2012. Population dynamics of major insect pests and their natural enemies on cabbage under new alluvial zone of West Bengal. J. Plant Prot. Sci., 5(1): 42-49.

Rohilla, 2015. Study of host preference and the comparison of some biological characteristics of Bemisia tabasi (Genn.) on mustard varieties. J. Plant Prot. Res., 53(2): 47-52.

Sahito,H.A.,A.G.Lanjar and B.Mal.2010. Studies on population dynamics of sucking insect pests of mustard crop (Brassica campestris). Pak. J. Agric. Eng. Vet. Sci., 26(1): 66-74.

Saljoqi, 2006. Insect pests of Canola crop (other 
than aphid). J. Agric. Biol. Sci., 1 (4): 19-21.

Singh and Premchand. 1995. Bakhetia and Arora 1986. Bioecology of painted bug (Bagrada cruciferarum) on seed crop of cauliflower (Brassica oleracea) var.(botrytis) Subvar. Indian J. Agric. Sci., 63(1): 676-678.

Singh, 2006. Nonpreference of whitefly for oviposition in mustard genotypes. J. Agric. Sci., 59(4): 112-117.

Toscano, 2012. Population dynamics of major insect pests and their natural enemies on cabbage under new alluvial zone of West Bengal. J. Plant Prot. Sci., 5(1): 42-49.

Verma, 2013. Effect of date of sowing on the incidence of insect pests of rape and mustard. J. Int. Sci., 7(4): 420-425. 